I. - PIG FEEDING

\title{
Further contribution to the study of requirements for maintenance in the pig
}

\author{
A. M. LEROY \\ 74 , vue du Château, \\ 95320 Saint-Leu-la-Forêt
}

\begin{abstract}
Using the abundant amount of data supplied by the $+2+$ th " Beretning fra Statens Husdyrbrugsforsog "published in Denmark in 1975, we verified the accuracy of the conclusions formulated in our own paper published almost at the same time in the "Annales de Zootechnie " of I.N.R.A. According to this, the requirements of pigs for maintenance can be slightly changed when the diets offered to the animals are particularly rich in poorly digestible feeds. Under these conditions, it is advisable to determine the energy requirements of the animals according to a method based on net energy and not on metabolisable energy as preconised by some authors. During the course of our study, emphasis has been laid on the large differences that might exist between animals having been subjected to a long and severe selection, with respect to the rhythm of daily protein and fat gain during the growing period.
\end{abstract}

\section{Partial or total replacement of maize by milo corn in pigs subjected to restrieted and isoproteic feeding}

\author{
J. CASTAING, M. LEUILLET \\ Association généralc des Producteurs de Maüs, \\ 1. place $S$. de Lestapis, \\ 64000 Pau \\ Institut Technique des Céréales et des Fonrrages, \\ 8, avenue du Président Wilson, \\ 75116 Paris
}

In the present trial, maize was partially or totally replaced by milo corn $(25,50$ and $79 \mathrm{p}$. 100 of the diet) in pigs subjected to restricted feeding with diets containing $16-17$ p. Ioo crude protein 